\title{
Integrating Health Belief Model in Nutrition Education for Individuals with Cardiometabolic Risk: The State-Of-The-Art
}

\section{Wan Ling Chiang, Barakatun Nisak Mohd Yusof \& Azrina Azlan}

To Link this Article: http://dx.doi.org/10.6007/IJARBSS/v11-i19/11743 DOI:10.6007/IJARBSS/v11-i19/11743

Received: 08 October 2021, Revised: 10 November 2021, Accepted: 24 November 2021

Published Online: 17 December 2021

In-Text Citation: (Chiang et al., 2021)

To Cite this Article: Chiang, W. L., Yusof, B. N. M., \& Azlan, A. (2021). Integrating Health Belief Model in Nutrition Education for Individuals with Cardiometabolic Risk: The State-Of-The-Art. International Journal of Academic Research in Business and Social Sciences, 11(19), 381-403.

Copyright: (C) 2021 The Author(s)

Published by Human Resource Management Academic Research Society (www.hrmars.com)

This article is published under the Creative Commons Attribution (CC BY 4.0) license. Anyone may reproduce, distribute, translate and create derivative works of this article (for both commercial and non-commercial purposes), subject to full attribution to the original publication and authors. The full terms of this license may be seen

at: http://creativecommons.org/licences/by/4.0/legalcode

Special Issue Title: Youth and Community Wellness, 2021, Pg. 381 - 403

http://hrmars.com/index.php/pages/detail/IJARBSS

Full Terms \& Conditions of access and use can be found at http://hrmars.com/index.php/pages/detail/publication-ethics 


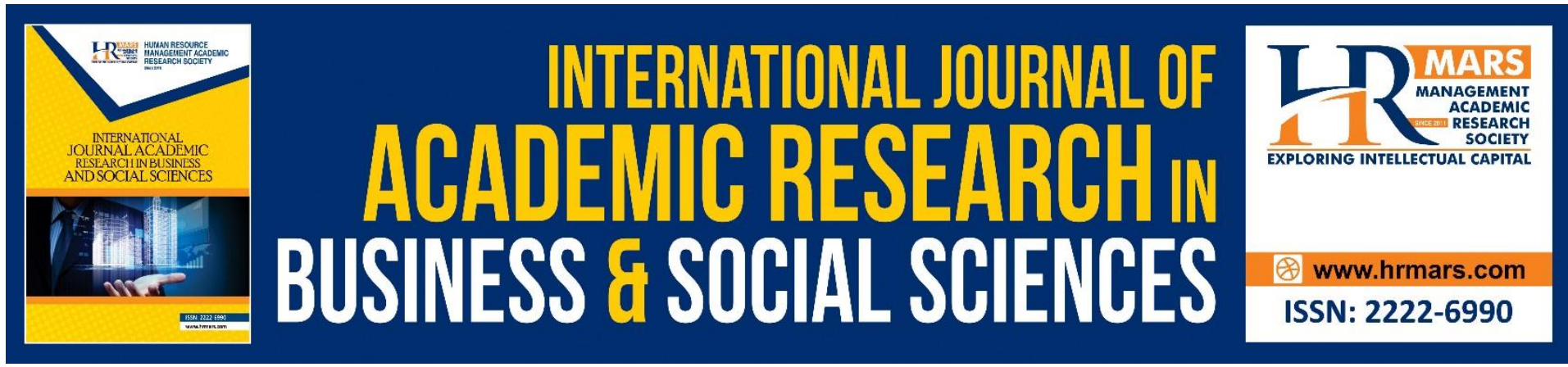

\title{
Integrating Health Belief Model in Nutrition Education for Individuals with Cardiometabolic Risk: The State-Of-The-Art
}

\author{
Wan Ling Chiang ${ }^{1}$, Barakatun Nisak Mohd Yusof ${ }^{1,2}$ \& Azrina \\ $\mathrm{Azlan}^{3}$ \\ ${ }^{1}$ Department of Dietetics, Faculty of Medicine and Health Sciences, Universiti Putra \\ Malaysia, 43400 Serdang, Selangor, Malaysia, ${ }^{2}$ Institute of Social Science Studies, Putra \\ Infoport, Universiti Putra Malaysia, 43400 Serdang, Selangor, Malaysia, ${ }^{3}$ Department of \\ Nutrition, Faculty of Medicine and Health Sciences, Universiti Putra Malaysia, 43400 \\ Serdang, Selangor, Malaysia. \\ Corresponding Author Email: bnisak@upm.edu.my
}

\begin{abstract}
While nutrition education modifies dietary habits, the impact is not sustainable over time. Integrating Health Belief Model (HBM) in nutrition education may aid in sustaining the improvement. This article determines the impact of integrating the HBM in nutrition education for individuals with cardiometabolic risk (CMR) to improve CMR markers, knowledge and dietary habits, especially regarding calories and nutrients of concern. We conducted a comprehensive search using online databases (Ovid LWW, PubMed, and Scopus (Elsevier)) for full-text articles published in the English language for the past ten years from January 2011 until August 2021. The included studies used controlled intervention among individuals with CMR defined using 'Harmonised' definitions by the International Diabetes Federation Task Force. The Quality Assessment Tool for Controlled Intervention Studies assessed the study quality. Seven studies, mainly from Iran, Iraq, Qatar and Greece, were included in this review, involving 1055 participants with CMR. Study quality ranged from fair to good. Most of the intervention studies did not blind the participants, providers and outcome assessors to group assignments. Integrating HBM in nutrition education with study duration between three to 12 months effectively improved some dietary habits, physical activity levels, knowledge, health belief, anthropometric and CMR factors. Integrating HBM in nutrition education positively impacted the outcome measures in individuals with CMR. The need for HBM is evident in improving dietary habits, particularly the calories intake and the nutrient of concern, including carbohydrates, fats, and dietary sugar. Modifying to a better quality of nutrients, such as antioxidants warrant further investigation.
\end{abstract}

Keywords: Intervention (Education), Dietary Intake, Health Belief, Cardiometabolic Risk Factor, Adult 


\section{Introduction}

The increasing burden of metabolic syndrome (MetS) has become a global public health issue over the last few decades. It contributes to the economic burdens of individuals and society decreases the quality of life and potential lifespan (Saboya et al., 2016). Cardiometabolic risk (CMR) is a term used to estimate an individual's chances of developing certain diseases, such as type 2 diabetes (T2DM) and cardiovascular disease (CVD) (Agyei-Mensah \& De-Graft Aikins, 2010). Unhealthy lifestyles, including unhealthy dietary habits, contribute to CMR development (Olatona et al., 2018).

A diet high in refined carbohydrates, dietary sugar and fats and low in fruits and vegetables is associated with CMR-related complications (Giugliano et al., 2008; L. A. te Morenga et al., 2013 , 2014). Restricting dietary carbohydrate intake induced fat loss and weight loss, which reduced the CMR-related complications (Fechner et al., 2020; Timóteo, 2018). A recent metaanalysis of randomised controlled trials (RCT) reported that dietary sugars affect blood pressure, serum lipids and body weight, and the mechanisms are both dependent and independent of weight gain (L. A. te Morenga et al., 2013, 2014). Besides fibre, vitamins and minerals, fruits and vegetables also contain antioxidants, which play a role in preventing and treating CMR-related complications by acting as scavengers of free radicals and other reactive species (Bellastella et al., 2015). Adhering to dietary recommendations, particularly low dietary sugar, may be challenging to sustain. Hence, other dietary approaches and supports, such as incorporating psychosocial theories during the development of nutrition intervention, are necessary to sustain the long-term behaviour change.

Nutrition education focusing on lifestyle modification reported improvement in CMR and behavioural lifestyle factors at the end of the intervention, but the impact was not sustained over time (Choo et al., 2016). The unsustainable impact may be due to the decreased motivation in maintaining healthy lifestyle behaviour where participants become discouraged from following a healthy diet. Maintaining the pleasure of eating is one area that needs to be focused on for the sustainability of behaviour change. Hence, using a theoretical framework in the development of interventions may aid in improving the success of the interventions. For instance, the UK Medical Research Council recommends using a theory to develop interventions and provide intervention hypotheses (Tougas et al., 2015).

The Health Belief Model (HBM) is one of the psychosocial theories used to study individuals' responses to symptoms and their responses to a diagnosed disease (Glanz et al., 2008; Janz \& Becker, 1984). It was first developed in the early 1950s to explore why individuals' widespread failure to participate in disease preventive programmes or screening tests to prevent and treat diseases (Glanz et al., 2008; Janz \& Becker, 1984). The HBM consists of five constructs: perceived susceptibility, perceived seriousness, perceived benefits, perceived barriers and self-efficacy. The rationale of this theory is that individuals are more likely to follow the recommended action if they believe that they are susceptible to the diseases, and adhering to the recommendation would reduce the risk. Also, they must feel that the benefits of adhering to the recommendation outweigh the barriers to follow the advice. The readiness to take action is also influenced by environmental events such as media publicity (cues to action) (Janz \& Becker, 1984). Figure 1 shows the Health Belief Model components and their linkages. 


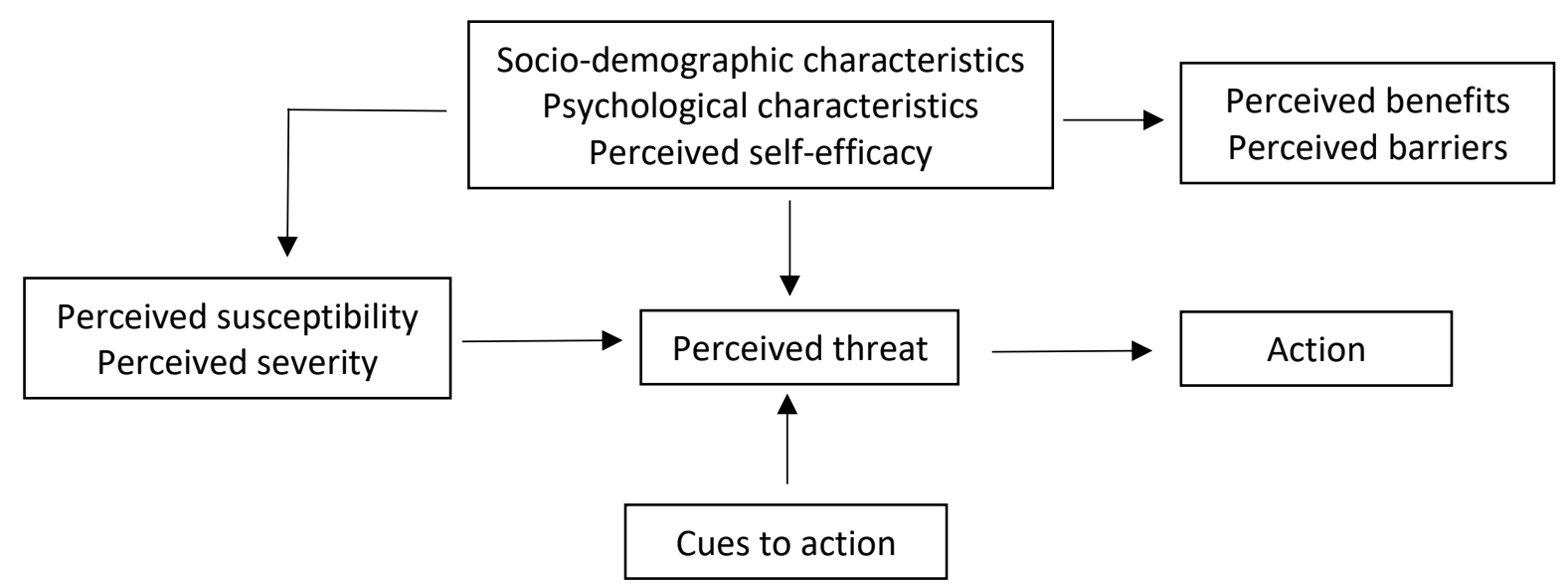

Figure 1: Health Belief Model Components and Linkages

The HBM theory has been applied in various studies to deliver information to change perceptions and reduce barriers. For instance, RCT had utilised HBM constructs in developing intervention programmes of various areas, including T2DM, osteoporosis, cancer, heart failure, consumption of unhealthy snacks and anxiety management, as well as obeying traffic regulations and prevention of school injuries (Alidosti et al., 2012; Baghianimoghadam et al., 2012, 2013; Farhadi et al., 2014; Fathi et al., 2017; Ghavami et al., 2016; Jeihooni et al., 2015; Mahmoud et al., 2018; Petersen et al., 2019; Shahnazi et al., 2015). Furthermore, their findings showed positive outcomes in the intervention group when compared to the control group.

The use of HBM in nutrition education among individuals with CMR may improve the success of the intervention. It helps to improve the CMR markers, knowledge and dietary habits, particularly the nutrients of concern (carbohydrate, dietary sugar, fats and calorie). This may, in turn, result in improving the risk factors of cardiometabolic and quality of life. To our knowledge, no study has systematically investigated and summarised the impact of incorporating HBM in nutrition education for individuals with CMR. Thus, this scoping review was conducted to determine the current state-of-the-art integrating the HBM in nutrition education for individuals with CMR.

\section{Methods}

This review followed the reporting guidelines outlined in the Preferred Reporting Items for Systematic Reviews and Meta-Analyses extension for Scoping Reviews (PRISMA-Scr) published by Enhancing the Quality and Transparency of Health Research (EQUATOR) (Equator, 2020).

\section{Search selection}

We conducted a comprehensive search using online databases (Ovid LWW, PubMed, and Scopus [Elsevier]) for the literature that integrated HBM into nutrition education in individuals with CMR. The included studies used controlled intervention among individuals with CMR defined using 'Harmonised' definitions by the International Diabetes Federation Task Force. Manual searching technique was used and the search strategy comprised of terms for intervention ["controlled intervention", "controlled trial", "intervention"], HBM ["health belief"], nutrition ["nutrition"] and cardiometabolic risk ["cardiometabolic", "metabolic 
syndrome", "hypertension", "blood pressure", "Diabetes Mellitus", "blood glucose", "dyslipidaemia", "hyperlipidaemia" and "hypercholesterolaemia"]. The search strategy included free text and subject heading terms. The snowball sampling technique was applied to identify relevant articles through references list in relevant articles that might not be indexed in the databases searched.

\section{Study Selection}

Titles and abstracts for relevant articles were examined. Duplicate articles were identified and removed. The articles were then screened for suitability. The full-text of relevant articles were then retrieved, examined and reviewed by two reviewers (WLC and BNMY). The full-text articles that were irrelevant were excluded. Disagreements were resolved by a third reviewer (AA).

We included controlled intervention based on HBM in individuals with CMR for the last ten years, from January 2011 until August 2021. Articles had to be peer-reviewed and published in the English language. The target population was adults aged 18 years old and above. Based on the 'Harmonized' definitions by the International Diabetes Federation (IDF) Task Force, $\mathrm{CMR}$ is defined as the presence of risk factors such as high waist circumference, high blood pressure, having T2DM or high fasting blood glucose, high triglyceride or low high-density lipoprotein (Alberti et al., 2009). Studies of individuals with diabetes, hypertension and dyslipidaemia were also included.

\section{Data Extraction}

Data were extracted by a single reviewer using the Cochrane Collaboration data extraction form: First author's family name, year of publication, study design, study purpose, target population, sample size, participants' characteristics (age, gender and health status), reference period, exposure and assessment methods, statistical analysis and findings. The extracted data were then reviewed and validated by a second reviewer.

\section{Study Quality}

The quality of the articles was evaluated using the Quality Assessment Tool for Controlled Intervention Studies (National Heart Lung and Blood Institute, 2014). This checklist assessed the articles by reviewing the study description, randomisation method, treatment allocation, blinding of participants, providers and outcome assessor, the similarity of baseline data between groups, overall drop-out rate and drop-out rate between groups, the similarity of background treatments, use of validated instruments, statistical power and sample size determination, identification of outcomes before analyses and the use of intention-to-treat analysis. Articles were rated as a poor, fair or good quality based on the score of the criteria outlined. Information on study quality can be found in the online supplementary material (File 1).

\section{Data Synthesis}

Data were synthesised based on the outcomes interest. The data consisted of biochemical measures [blood glucose and lipid profiles], blood pressure, health belief, knowledge, attitude and practice [KAP], dietary habits and physical activity level. Then, the data were comprehensively examined regarding the data adjustment and statistical analysis. 


\section{Results}

\section{Identification of Potential Studies}

The database search found 449 articles, and other sources found 23 articles (Figure 2). After removing the duplicated articles, a total of 446 results were screened and resulted in 35 fulltext articles assessed for eligibility. The team excluded another 28 articles that did not meet the selection criteria and included seven articles for this review.

\section{Characteristics of the Included Studies}

Three studies were published in the year 2013, two in the year 2014 and two in the year 2018. In terms of the geographic scope of the studies, the predominant of the studies were conducted in Iran $(n=618)$. The remaining studies were divided among several countries, which includes Greece $(n=108)$, Iraq $(n=39)$ and Qatar $(n=290)$. There are 1055 participants, $30 \%$ male, age 25 to 74 years old and the majority with T2DM from all these seven studies.

\section{Type of Methods and Design}

All included studies used quantitative methods and RCT design. All studies randomly assigned the participants to Intervention Group (IG) and Control Group (CG). The intervention of the studies was developed based on the HBM as a theoretical framework. The HBM constructs consist of perceived susceptibility, perceived seriousness, perceived benefits, perceived barriers and self-efficacy. The education sessions were presented as lecture classes, diet counselling and group discussion. The content of the intervention was mainly regarding complications of CMR, nutrition and healthy diet, physical activity and self-care and selfefficacy behaviour. 


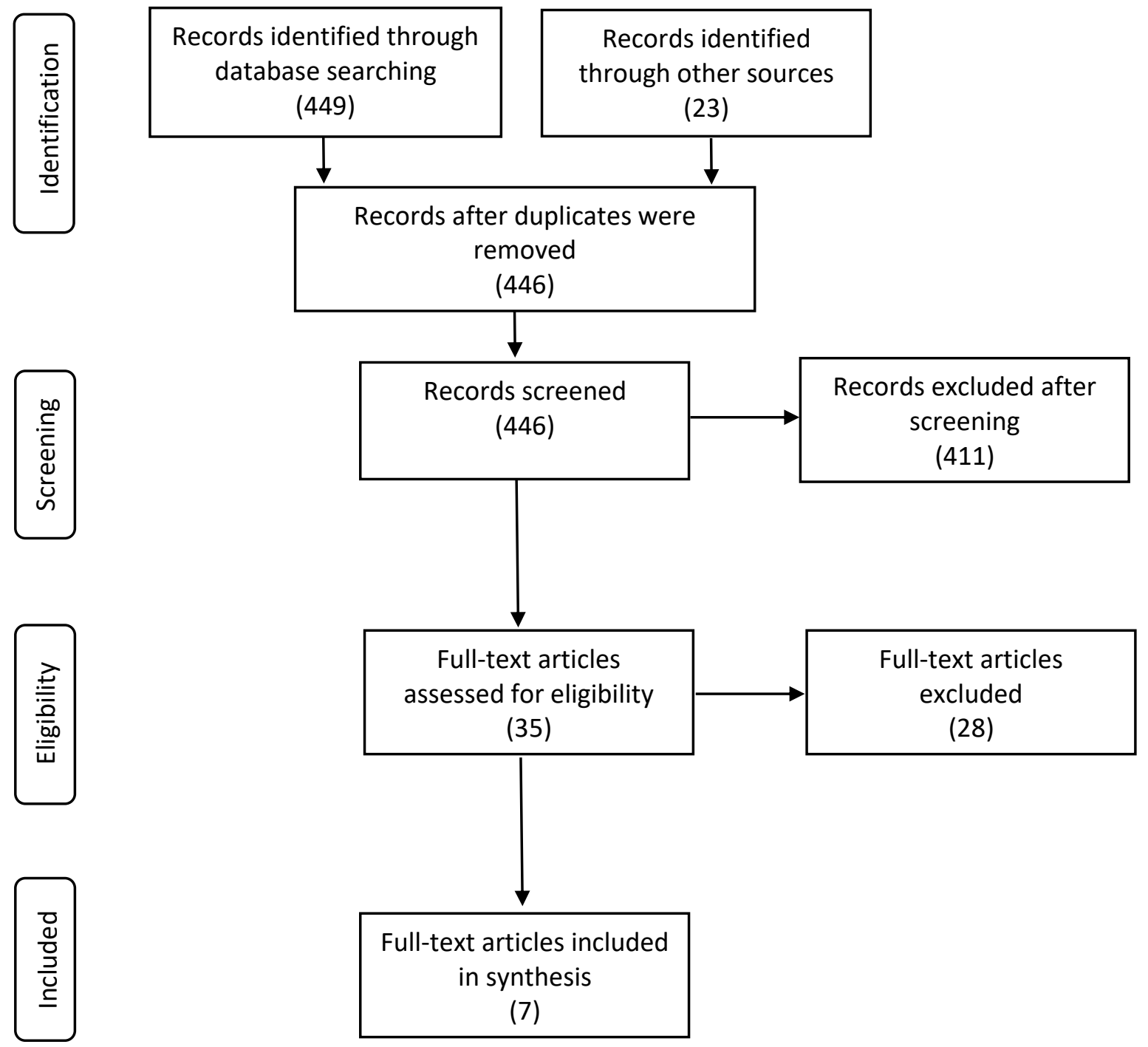

Figure 2. Flowchart of the literature search process for nutrition intervention based on Health Belief Model in individuals with cardiometabolic risk.

\section{Quality Appraisal of the Included Studies}

Study quality ranged from 'fair' to 'good'. The main limitation of the RCT was that study participants, providers and outcome assessors were not blinded to group assignments. This is due to the nature of the study design, where it is not possible to disguise the difference in education modules. For instance, participants in the intervention group participated in the education sessions, whereas participants in the control group did not. Hence, participants knew the group that they were assigned. Only one study had more than $20 \%$ overall drop-out rate, a differential drop-out rate of more than 15\% at the endpoint (Mohamed et al., 2013). Three studies did not report the method of randomisation (Jalilian et al., 2014; Petrogianni et al., 2013; Zareban et al., 2014). All studies had similar baseline characteristics and used validated and reliable measures to assess the outcomes.

\section{Type of Health-related Outcomes Assessed}

The included studies investigated the impact of nutrition education based on HBM in individuals with CMR. Information includes the first author's family name, year of publication, 
study design, study purpose, target population, sample size, participants' characteristics (age, gender and health status), reference period, exposure and assessment methods, statistical analysis, and findings (Table 1).

All studies showed significant positive impacts on the outcome measures. Three studies that assessed the impact of nutrition education showed improvement in the HBM constructs in the Intervention Group (IG) as compared to the Control Group (CG) (Bayat et al., 2013; Jalilian et al., 2014; Mohammadi et al., 2018). For instance, Jalilian et al. (2014) reported significant improvements in perceived susceptibility $(p=0.002)$, severity $(p<0.001)$, benefit $(p<0.001)$, barriers $(p<0.001)$ and self-efficacy $(p<0.001)$ among IG compared to CG, in a study conducted among T2DM Iranian patients (Jalilian et al., 2014).

Two studies that determined the effects of nutrition education on KAP and self-care behaviour reported significant improvements in these parameters in the IG after the intervention among T2DM patients from Qatar and Iran, respectively (Mohamed et al., 2013; Zareban et al., 2014). For instance, Mohamed et al. (2013) reported that the IG had improvement in Diabetes knowledge $(5.9 \%, p<0.001)$, attitude $(6.56 \%, p<0.001)$ and practice $(6.52 \%, p=0.001)$ compared to the CG, among T2DM patients in Qatar.

Two studies conducted among T2DM adults in Iraq and hypercholesterolaemia adults in Greece showed a significant difference in dietary intake and physical activity level postintervention (Abdulah et al., 2018; Petrogianni et al., 2013). A recent RCT was conducted in Greece to evaluate a multi-component lifestyle intervention on CMR indices, physical activity levels and diet quality in hypercholesterolaemic adults (Petrogianni et al., 2013). The study showed that there was a significant improvement in milk intake $(p=0.021)$, dark green/orange vegetables and legume $(p=0.050)$, total Healthy Eating Index score $(p=0.045)$, and a higher daily number of steps ( $p=0.005$ ) in the IG as compared to the CG (Petrogianni et al., 2013). Total fruit, whole fruit, total grains, meat and beans, and oils showed no significant difference between the IG and CG (Petrogianni et al., 2013). There was an improvement in the calories from solid fats, alcoholic beverages and added sugars' score in the 3-month value of the IG compared to their baseline values (Petrogianni et al., 2013). Similarly, Abdulah et al. (2018) conducted a nutrition education among patients with T2DM in Iraq and found that IG had a higher intake of fruits and vegetables $(p<0.001)$, a lower intake of full-fat spread $(p=0.007)$ and full-fat cheese $(p=0.009)$, and higher frequency and duration of walking $(p=0.001)$ compared to the CG at 3-month follow-up (Abdulah et al., 2018). Other dietary items such as cakes and biscuits, confectionery, sugary drinks and high-fat/sugar snacks between meals were also determined in the study but found no significant difference in the CG and IG (Abdulah et al., 2018). No improvement in dietary sugars suggests the need for a better quality of sugars that contain other properties, including antioxidants.

Four studies, conducted in Iraq, Iran, Qatar and Greece, respectively, determined the effect of nutrition education on body mass index (BMI) (Abdulah et al., 2018; Mohamed et al., 2013; Mohammadi et al., 2018; Petrogianni et al., 2013). The findings of these studies vary, with three studies reported a significant difference in BMI between IG and CG and one did not. Abdulah et al (2018) found no significant difference in BMI between IG and CG at follow-up ( $p=0.378$ ) among T2DM patients in Iraq (Abdulah et al., 2018). At the same time, Mohamed et al., (2013) reported a significant difference in BMI between IG and CG among T2DM 
patients in Qatar, where IG $\left(34.4 \pm 5.27 \mathrm{~kg} / \mathrm{m}^{2}\right)$ had a higher BMI than CG $\left(32.7 \pm 3.33 \mathrm{~kg} / \mathrm{m}^{2}\right)$ at follow-up (Mohamed et al., 2013). Mohammadi et al., (2018) revealed that there was a reduction in BMI of IG $\left(-1.4 \mathrm{~kg} / \mathrm{m}^{2}, p=0.001\right)$, whereas an increase in BMI of CG $\left(0.3 \mathrm{~kg} / \mathrm{m}^{2}\right.$, $p=0.001$ ) (Mohammadi et al., 2018) at post-intervention among T2DM patients in Iran.

Several studies revealed improvement in biochemical and clinical measures after the nutrition education (Abdulah et al., 2018; Mohamed et al., 2013; Mohammadi et al., 2018). For instance, a culturally sensitive, structured education programme was conducted in Qatar among patients with T2DM (Mohamed et al., 2013). At 1-year follow-up, there were significant differences in fasting blood glucose $(-0.92 \mathrm{mmol} / \mathrm{L}, p=0.022)$ between IG and CG (Mohamed et al., 2013). In terms of clinical outcome, Petrogianni et al., (2013) reported that at post-intervention, the IG significantly decreased both systolic (SBP) and diastolic blood pressure (DBP) (SBP: $-6.5 \mathrm{mmHg}, 95 \% \mathrm{Cl}:-10.3$ to -2.7 ; DBP: $-3.4 \mathrm{mmHg}, 95 \% \mathrm{Cl}:-6.6$ to -0.008 ) compared to the baseline values, among hypercholesterolaemia adults in Greece (Petrogianni et al., 2013).

\section{Discussion}

This review determines the current state-of-the-art in integrating the HBM in nutrition education for individuals with CMR. A total of seven studies were included and were mainly from Iran, Iraq, Qatar and Greece. No study was identified conducted in the Southeast Asia region, including Malaysia, that determines the impact of HBM in nutrition education for individuals with CMR to improve dietary habits, particularly regarding the nutrients of concern.

In our review, KAP and self-care behaviour improved significantly in IG in Iran $(n=138)$ and Qatar ( $n=290$ ) (Mohamed et al., 2013; Zareban et al., 2014). Sufficient knowledge about the disease, prognosis, complications, and treatment reduce the prevalence of MetS. The improvement could be related to a higher health literacy (Yokokawa et al., 2016). Nevertheless, a recent cross-sectional study found no significant association between knowledge and health literacy (Emiral et al., 2021). Knowledge does not always lead to the practical implementation of positive behavioural change. The health belief may be one of the underlying factors that influence the health literacy and prevalence of MetS.

Our review also showed that nutrition education based on HBM improved the HBM constructs in IG compared to the CG in studies conducted among T2DM Iranian adults (Bayat et al., 2013; Jalilian et al., 2014; Mohammadi et al., 2018). The same findings were obtained from other interventional studies in Iran and Netherlands (Baghianimoghadam et al., 2012; Shamsi et al., 2010; van der Heijden et al., 2012). 
INTERNATIONAL JOURNAL OF ACADEMIC RESEARCH IN BUSINESS AND SOCIAL SCIENCES

Vol. 11, No. 19, Youth and Community Wellness, 2021, E-ISSN: 2222-6990 @ 2021 HRMARS

Table 1: Summary of studies that integrate Health Belief Model nutrition education in individuals with CMR.

\begin{tabular}{|c|c|c|c|c|c|c|c|}
\hline $\begin{array}{l}\text { Author, } \\
\text { year } \\
\text { published, } \\
\text { country }\end{array}$ & $\begin{array}{l}\text { Outcome } \\
\text { measured }\end{array}$ & $\begin{array}{l}\text { Target } \\
\text { population, } \\
\% \text { male, } \\
\text { sample size, } \\
\text { age }\end{array}$ & $\begin{array}{l}\text { Interventi } \\
\text { on length }\end{array}$ & $\begin{array}{l}\text { Study } \\
\text { Duratio } \\
\text { n } \\
\text { (months } \\
\text { ) }\end{array}$ & $\begin{array}{l}\text { Exposure and } \\
\text { assessment } \\
\text { method }\end{array}$ & Statistical analysis & $\begin{array}{l}\text { Findings } \\
\text { (IG vs CG) }\end{array}$ \\
\hline $\begin{array}{l}\text { Bayat et } \\
\text { al., 2013, } \\
\text { Iran }\end{array}$ & $\begin{array}{l}\text { HBM } \\
\text { constructs }\end{array}$ & $\begin{array}{l}\text { Patients } \\
\text { with T2DM } \\
(n=120), \\
44 \% \text { male, } \\
\text { aged } 36 \text { to } \\
55 \text { years old }\end{array}$ & $\begin{array}{l}\text { Two } 30 \text { to } \\
45 \\
\text { minutes } \\
\text { sessions }\end{array}$ & $\begin{array}{l}6 \\
\text { months }\end{array}$ & $\begin{array}{l}\text { HBM } \\
\text { constructs } \\
\text { and self- } \\
\text { efficacy } \\
\text { questionnair } \\
\text { e }\end{array}$ & $\begin{array}{l}\text { - Descriptive } \\
\text { statistics } \\
\text { - Chi-square test } \\
\text { - Fisher's exact } \\
\text { test } \\
\text { - Independent t- } \\
\text { test } \\
\text { - ANCOVA } \\
\text { - Generalised } \\
\text { Estimating } \\
\text { Equation }\end{array}$ & $\begin{array}{l}\text { - HBM constructs: Positive and } \\
\text { significant impact }(p<0.001) \text { at } 3 \\
\text { and } 6 \text { months after the } \\
\text { intervention }\end{array}$ \\
\hline $\begin{array}{l}\text { Mohamed } \\
\text { et al., } \\
2013, \\
\text { Qatar }\end{array}$ & $\begin{array}{l}\text { Glucose } \\
\text { control, } \\
\text { weight, } \\
\text { KAP }\end{array}$ & $\begin{array}{l}\text { Patients } \\
\text { with T2DM } \\
\text { ( } n=290) \text {, } \\
31 \% \text { male, } \\
\text { aged } 52 \text { to } \\
55 \text { years old }\end{array}$ & $\begin{array}{l}\text { Four } \\
\text { sessions, } \\
\text { lasting for } \\
3 \text { to } 4 \\
\text { hours }\end{array}$ & $\begin{array}{l}12 \\
\text { months }\end{array}$ & $\begin{array}{l}\text { - Validated } \\
\text { KAP } \\
\text { questionnair } \\
\text { e }\end{array}$ & $\begin{array}{l}\text { - Descriptive } \\
\text { statistics } \\
\text { - Mann-Whitney } \\
\text { U test } \\
\text { - ANCOVA }\end{array}$ & $\begin{array}{l}\text { - Anthropometry: Significant change } \\
\text { in BMI ( } p<0.001) \\
\text { - Biochemical: Improved glucose } \\
\text { level ( } p=0.022) \\
\text { - KAP: Significant improvement } \\
(p<0.001)\end{array}$ \\
\hline $\begin{array}{l}\text { Petrogian } \\
\text { ni et al., } \\
2013, \\
\text { Greece }\end{array}$ & $\begin{array}{l}\text { Blood } \\
\text { pressure } \\
\text { control, } \\
\text { physical } \\
\text { activity } \\
\text { levels and } \\
\text { diet quality }\end{array}$ & $\begin{array}{l}\text { Hypercholes } \\
\text { terolaemic } \\
\text { adults } \\
(\mathrm{n}=108), \\
54 \% \text { male, } \\
\text { mean age= }\end{array}$ & $\begin{array}{l}\text { Seven } \\
\text { hourly } \\
\text { sessions, } \\
\text { held } \\
\text { biweekly } \\
\text { for } 3 \\
\text { months }\end{array}$ & $\begin{array}{l}3 \\
\text { months }\end{array}$ & $\begin{array}{l}\text { - 3-day diet } \\
\text { record } \\
\text { - Healthy } \\
\text { Eating Index- } \\
2005 \text { score }\end{array}$ & $\begin{array}{l}\text { - Descriptive } \\
\text { statistics } \\
\text { - Repeated } \\
\text { measures } \\
\text { analysis of } \\
\text { variance }\end{array}$ & $\begin{array}{l}\text { - Blood pressure: Significant } \\
\text { improvement }(p<0.05) \\
\text { - Physical activity: Increased daily } \\
\text { number of steps ( } p=0.005) \\
\text { - Anthropometry: Significant weight } \\
\text { change }(p=0.021), \text { BMI }(p=0.019) \\
\text { and WC }(p=0.027)\end{array}$ \\
\hline
\end{tabular}


INTERNATIONAL JOURNAL OF ACADEMIC RESEARCH IN BUSINESS AND SOCIAL SCIENCES Vol. 11, No. 19, Youth and Community Wellness, 2021, E-ISSN: 2222-6990 @ 2021 HRMARS

\begin{tabular}{|c|c|c|c|c|c|c|c|}
\hline & & $\begin{array}{l}48.7 \text { years } \\
\text { old }\end{array}$ & & & & & $\begin{array}{l}\text { - Dietary habits: Improved scores for } \\
\text { 'milk' ( } p=0.021) \text {, 'dark } \\
\text { green/orange vegetables and } \\
\text { legumes' }(p=0.050) \text { and 'total HEI } \\
\text { score' }(p=0.045)\end{array}$ \\
\hline $\begin{array}{l}\text { Jalilian et } \\
\text { al., 2014, } \\
\text { Iran }\end{array}$ & $\begin{array}{l}\text { HBM } \\
\text { constructs }\end{array}$ & $\begin{array}{l}\text { Patients } \\
\text { with T2DM } \\
(n=120), \\
27 \% \text { male, } \\
\text { mean } \\
\text { age }=55 \\
\text { years old }\end{array}$ & $\begin{array}{l}\text { Six } \\
\text { sessions, } 6 \\
\text { weeks }\end{array}$ & $\begin{array}{l}2 \\
\text { months }\end{array}$ & $\begin{array}{l}\text { - Questionnair } \\
\text { e on HBM } \\
\text { and self- } \\
\text { managemen } \\
\text { t behaviour }\end{array}$ & $\begin{array}{l}\text { - Descriptive } \\
\text { statistics } \\
\text { - Chi-square test } \\
\text { - Independent t- } \\
\text { test }\end{array}$ & $\begin{array}{l}\text { - HBM constructs: Significant } \\
\text { improvement }(p<0.05) \text { at } 2 \text { months } \\
\text { after the intervention }\end{array}$ \\
\hline $\begin{array}{l}\text { Zareban } \\
\text { et al., } \\
2014 \text {, Iran }\end{array}$ & $\begin{array}{l}\text { Knowledge } \\
\text {, attitude } \\
\text { and self- } \\
\text { care } \\
\text { behaviours }\end{array}$ & $\begin{array}{l}\text { Female } \\
\text { patients } \\
\text { with T2DM } \\
(n=138), 0 \% \\
\text { male, aged } \\
48 \text { to } 74 \\
\text { years old } \\
\end{array}$ & $\begin{array}{l}\text { Five } \\
\text { sessions in } \\
1 \text { month }\end{array}$ & $\begin{array}{l}3 \\
\text { months }\end{array}$ & $\begin{array}{l}\text { - Validated } \\
\text { questionnair } \\
\text { e on } \\
\text { knowledge, } \\
\text { attitude and } \\
\text { self-care } \\
\text { behaviours } \\
\end{array}$ & $\begin{array}{l}\text { - Descriptive } \\
\text { statistics } \\
\text { - Inferential test } \\
\text { - Chi-square test } \\
\text { - Paired t-test }\end{array}$ & $\begin{array}{l}\text { - Knowledge, attitude and self-care } \\
\text { behaviours: Significant } \\
\text { improvement }(p<0.001)\end{array}$ \\
\hline $\begin{array}{l}\text { Abdulah } \\
\text { et al., } \\
2018 \text {, Iraq }\end{array}$ & $\begin{array}{l}\text { Glucose } \\
\text { control, } \\
\text { weight, } \\
\text { physical } \\
\text { activity } \\
\text { and dietary } \\
\text { habits }\end{array}$ & $\begin{array}{l}\text { Patients } \\
\text { with T2DM } \\
\text { ( } n=39), 31 \% \\
\text { male, aged } \\
25 \text { years old } \\
\text { and above }\end{array}$ & $\begin{array}{l}\text { Three 2- } \\
\text { hour } \\
\text { sessions, } 3 \\
\text { weeks }\end{array}$ & $\begin{array}{l}3 \\
\text { months }\end{array}$ & $\begin{array}{l}\text { - UK Diabetes } \\
\text { \& Diet } \\
\text { Questionnair } \\
\text { e } \\
\text { - International } \\
\text { Physical } \\
\text { Activity } \\
\text { Questionnair } \\
\text { e-Short } \\
\text { Form }\end{array}$ & $\begin{array}{l}\text { - Descriptive } \\
\text { statistics } \\
\text { - Inferential } \\
\text { statistical tests } \\
\text { - Mann-Whitney } \\
\text { U test } \\
\text { - Independent t- } \\
\text { test }\end{array}$ & $\begin{array}{l}\text { - Anthropometry: Comparable } \\
\text { change in BMI ( } p=0.378) \\
\text { - Biochemical: Improved glucose } \\
\text { level ( } p=0.009) \\
\text { - Physical activity: Increased walking } \\
\text { activity ( } p<0.001) \\
\text { - Dietary habits: Improved intake of } \\
\text { vegetable, fruit, and bread, and } \\
\text { reduced intake of full-fat cheese } \\
\text { and full-fat spread ( } p<0.05)\end{array}$ \\
\hline
\end{tabular}


INTERNATIONAL JOURNAL OF ACADEMIC RESEARCH IN BUSINESS AND SOCIAL SCIENCES Vol. 11, No. 19, Youth and Community Wellness, 2021, E-ISSN: 2222-6990 @ 2021 HRMARS

\begin{tabular}{|c|c|c|c|c|c|c|c|}
\hline $\begin{array}{l}\text { Mohamm } \\
\text { adi et al., } \\
2018 \text {, Iran }\end{array}$ & $\begin{array}{l}\text { Lipid } \\
\text { profile, } \\
\text { glucose } \\
\text { control, } \\
\text { weight, } \\
\text { nutrition } \\
\text { knowledge } \\
\text {, health } \\
\text { beliefs and } \\
\text { quality of } \\
\text { life }\end{array}$ & $\begin{array}{l}\text { Patients } \\
\text { with T2DM } \\
\text { ( } n=240) \text {, NA, } \\
\text { aged } 30 \text { to } \\
65 \text { years old }\end{array}$ & $\begin{array}{l}\text { Eight } \\
\text { sessions } \\
\text { ( } 2 \text { hours } \\
\text { per } \\
\text { session), } \\
12 \text { weeks }\end{array}$ & $\begin{array}{l}6 \\
\text { months }\end{array}$ & $\begin{array}{l}\text { - Validated } \\
\text { knowledge } \\
\text { questionnair } \\
\text { e } \\
\text { - HBM } \\
\text { questionnair } \\
\text { e } \\
\text { - Diabetes } \\
\text { Quality of } \\
\text { Life } \\
\text { questionnair } \\
\text { e }\end{array}$ & $\begin{array}{l}\text { - Descriptive } \\
\text { statistics } \\
\text { - Two-way } \\
\text { repeated } \\
\text { measure ANOVA } \\
\text { - Independent t- } \\
\text { tests } \\
\text { - Chi-square test } \\
\text { - Paired t-test } \\
\text { - Mann-Whitney } \\
\text { test } \\
\text { - Friedman } \\
\text { repeated } \\
\text { measure test }\end{array}$ & $\begin{array}{l}\text { - Biochemical: Improved glucose } \\
\text { level and lipid profiles (TC, HDL-C, } \\
\text { LDL-D, TG) ( } p=0.001) \\
\text { - Anthropometry: Significant change } \\
\text { in BMI ( } p<0.001) \\
\text { - Knowledge: Significant } \\
\text { improvement ( } p=0.001) \\
\text { - Health belief: Significant } \\
\text { improvement ( } p=0.001) \\
\text { - Quality of life: Significant } \\
\text { improvement ( } p=0.001)\end{array}$ \\
\hline
\end{tabular}

Abbreviation: BMI, body mass index; CG, control group; CMR, cardiometabolic risk; DBP, diastolic blood pressure; FBG, fasting blood glucose; HBM, Health Belief Model; HDL-C, HDL-cholesterol; IG, intervention group; KAP, knowledge, attitude and practice; LDL-C, LDL-cholesterol; NA, not available; SBP, systolic blood pressure; TC, total cholesterol; TG, triglyceride; T2DM, type 2 diabetes mellitus; WC, waist circumference. 
Implementing nutrition education based on HBM also produced a favourable change in some dietary habits and physical activity levels. Petrogianni et al (2013) reported improved diet quality, increased whole grains intake, and reduced calories from solid fats, alcoholic beverages, and added sugars in the IG after the intervention among hypercholesterolemic adults in Greece (Petrogianni et al., 2013). Meanwhile, Abdulah et al (2018) found that the IG had a higher intake of fruits and vegetables and a lower intake of full-fat spread and full-fat cheese than the CG at the 3-month follow-up among T2DM adults in Iraq (Abdulah et al., 2018). Other dietary items such as cakes, biscuits and confectionery showed no difference between the IG and CG at three months (Abdulah et al., 2018). Hence, a longer duration of 6month follow-up may yield more notable changes in dietary habits. Besides, modifying the type of sugars added with antioxidants may be an option.

In recent years, nutrition research has focused on increasing the intake of antioxidant-rich foods. This is because antioxidants and their phytochemicals contain bioactive compounds responsible for reducing the risk factors associated with CMR (Singh et al., 2015). Industries have produced alternatives of refined white sugars, which is sugar that is rich in antioxidants. Examples are brown sugar, maple syrup, agave nectar, molasses, honey, and date sugar (Phillips et al., 2009). The World Health Organization (WHO) recommended limiting free sugar intake, which should not exceed $10 \%$ of total energy intake (World Health Organization, 2015). Therefore, replacing refined white sugar with antioxidant sugar and consume it within the WHO recommendation may be an alternative strategy in influencing the metabolic complications and promote long-term behaviour change as the sweetness of the antioxidant sugar may maintain the pleasure of eating.

Studies have also shown increased physical activity levels in IG compared to CG at the end of the intervention (Abdulah et al., 2018; Petrogianni et al., 2013). In regards to behavioural change of dietary intake and physical activity level, the HBM constructs focused on the perceived susceptibility to the disease complications, perceived seriousness of the health conditions upon non-adherence to recommendations of dietary and physical activity, and perceived benefits and perceived barriers in changing the dietary intake and increasing physical activity. All these resulted in promising impacts. The absence of psychosocial theory may lead to a non-significant impact of nutrition education on lifestyle changes. For instance, an RCT with lifestyle intervention focusing on modifying the dietary intake among individuals at diabetes risk reported a non-significant difference in total calorie, carbohydrate, sucrose and fat between the IG and CG at the end of the 4-month intervention (Siddiqui et al., 2017).

Overweight and obesity contribute to the global burden of non-communicable disease (NCD), and weight loss can improve or prevent the obesity-related risk factors for NCD (Pérez Pérez et al., 2007). The commonly used measurement to determine overweight and obesity is the BMI (Pérez et al., 2007). Four studies, conducted in Iraq, Iran, Qatar and Greece, reported different findings in terms of BMI (Abdulah et al., 2018; Mohamed et al., 2013; Mohammadi et al., 2018; Petrogianni et al., 2013). This may be due to the difference in duration of followup, design of the CG (any education provided), and the education content. A study showed that behavioural lifestyle modifications were most prominent at three months of the intervention and would slowly re-bounded over the next nine months (Choo et al., 2016). Hence, BMI may vary at the different duration of follow-up. The outcome of CG depends on whether CG receives any education implementation. Implementation of education in CG may 
result in an insignificant difference in BMI between IG and CG. Lastly, the content of the education program for the IG, types of programmes (lecture class, diet counselling or discussion group), and frequency and duration of the session received by the IG would also affect the study outcomes.

Three studies, conducted in Iraq, Iran and Qatar, revealed improvement in biochemical measures after the nutrition education (Abdulah et al., 2018; Mohamed et al., 2013; Mohammadi et al., 2018). All three studies reported significant improvement in blood glucose level in IG at post-intervention $(p<0.05)$, suggesting that modifying behavioural lifestyle factors improved CMR (Abdulah et al., 2018; Mohamed et al., 2013; Mohammadi et al., 2018). Two studies measured lipid profiles (total cholesterol, HDL-cholesterol, LDL-cholesterol and triglycerides) at follow-up (Mohamed et al., 2013; Mohammadi et al., 2018). Mohammadi et al (2018) reported a significant difference in total cholesterol, HDL-cholesterol, LDLcholesterol and triglycerides between IG and CG at 6-month follow-up among T2DM adults in Iran (Mohammadi et al., 2018). However, Mohamed et al (2013) found that only LDLcholesterol was significantly different between IG and CG at 1-year follow-up among T2DM adults in Qatar (Mohamed et al., 2013). The difference between these studies may be due to differences in follow-up duration. Furthermore, CG received the same educational tool kit as IG, leading to the insignificant difference in lipid profiles between these two groups (Mohamed et al., 2013).

Petrogianni et al (2013) reported a significant reduction in the SBP and DBP of IG at postintervention compared to the baseline values among hypercholesterolaemia adults in Greece (Petrogianni et al., 2013). The finding may be related to the changes in dietary intake, physical activity level and weight loss in the IG, which was supported by a finding from meta-analyses. About $1 \mathrm{~kg}$ weight reduction leads to a reduction in SBP and DBP, ranging from 1.05 to 2.4 $\mathrm{mmHg}$ and from 0.92 to $1.5 \mathrm{mmHg}$, respectively (Neter et al., 2003; Staessen et al., 1988).

\section{Strengths and Limitations}

This review applied systematic and comprehensive search strategies in retrieving the relevant articles. All of the studies included in this review were controlled interventions, with quality ranged from 'fair' to 'good'. The outcome measure was assessed using valid and reliable measures, implemented consistently across all study participants. All studies had comparable baseline characteristics between IG and CG, and data were statistically analysed.

Only articles published in the English language were included in this review. This may result in missing relevant studies published in other languages. This review aimed to identify studies published ten years before the search. Hence, earlier evidence that may still be relevant were not included. In terms of the included studies, most of the participants, providers, and outcome assessors in the controlled interventions were not blinded to treatment group assignment due to the nature of the study design. Therefore, it is not possible to mask which groups the participants were assigned. Also, measurement bias might occur in the studies that utilised the self-report technique in collecting dietary intake.

\section{Future Recommendations}

Profound lifestyle changes to modify dietary habits of calorie, carbohydrate, fats and sugar, are significant lifestyle interventions to reduce CMR factors. For instance, reduced dietary 
sugar intake resulted in a reduction of body weight, blood pressure and serum lipids (L. A. te Morenga et al., 2013, 2014). Therefore, different dietary strategies have been developed to prevent and treat different metabolic complications associated with MetS. Examples are a low-calorie diet, low glycaemic index diet, a diet rich in total antioxidant capacity, and the Mediterranean diet (de la Iglesia et al., 2016; Goldenberg et al., 2021; Timóteo, 2018). Adherence to a low-calorie diet with increased physical activity is the core therapeutic approach for overweight and obese individuals with CMR (Hallberg et al., 2019).

Nevertheless, nutrition interventions focusing on low-calorie and low-carbohydrate diets for T2DM patients reported that the positive impacts were not sustained at follow-up (Hammer et al., 2008; Paisey et al., 1998; Snel et al., 2012; Wing et al., 1994). Hence, it is crucial to develop proper nutrition interventions that focus on long-term behaviour change. Integrating HBM in the development of nutrition intervention improves the sustainability of behaviour change. Other dietary strategies, support and methods are also necessary. Maintaining the pleasure of eating is one area that needs to be focused on for the sustainability of behaviour change.

We are currently conducting a study to determine the effectiveness of nutrition education in modifying sugar consumption and the impact of antioxidant sugar among individuals with CMR. This is pertinent as we know it is difficult to maintain long-term low dietary sugar intake. Substituting refined white sugar with antioxidant sugar and consuming a moderate amount of antioxidant sugar may be part of a practical solution in reducing the CMR. This review shows that integrating HBM in nutrition education among individuals with CMR would positively impact CMR-related outcomes. Hence, further controlled studies based on HBM are warranted to investigate the efficacy of antioxidant sugar in influencing the CMR.

\section{Conclusion}

Integrating HBM in nutrition education among individuals with CMR positively impacted some dietary habits, physical activity level, knowledge, health belief, anthropometric and CMR factors. The use of the HBM constructs: perceived seriousness, perceived susceptibility, perceived barriers, perceived benefits and self-efficacy, as the theoretical framework in developing the content of the intervention, plays a vital role in modifying the behavioural lifestyle factors. Although measurement tools were reliable and validated, there were limitations in the study design, particularly the blinding of the participants, providers, and outcome assessors.

\section{Disclosure of Relationships and Activities}

The authors have no relevant affiliations or financial involvement with any organisation or entity with a financial interest in or financial conflict with the subject matter or materials discussed in the manuscript.

\section{Funding Statement}

This work was funded by Central Sugar Refinery Sdn. Bhd., Malaysia [Research No 630025614001]. The sponsor was not involved in any aspect of the present study, including conceptualised the scoping review; collection, management, analysis and interpretation of the data; and preparation, review or approval of the article. 


\section{Supportive/Supplementary Material}

File 1: Quality appraisal of the included studies.

\section{References}

Abdulah, D. M., Hassan, A. B., Saadi, F. S., \& Mohammed, A. H. (2018). Impacts of selfmanagement education on glycaemic control in patients with type 2 diabetes mellitus. Diabetes and Metabolic Syndrome: Clinical Research and Reviews, 12(6). https://doi.org/10.1016/j.dsx.2018.06.007

Agyei-Mensah, S., \& De-Graft Aikins, A. (2010). Epidemiological transition and the double burden of disease in Accra, Ghana. Journal of Urban Health, 87(5), 879-897. https://doi.org/10.1007/s11524-010-9492-y

Alberti, K. G. M. M., Eckel, R. H., Grundy, S. M., Zimmet, P. Z., Cleeman, J. I., Donato, K. A., Fruchart, J. C., James, W. P. T., Loria, C. M., \& Smith, S. C. (2009). Harmonising the metabolic syndrome: A joint interim statement of the international diabetes federation task force on epidemiology and prevention; National heart, lung, and blood institute; American heart association; World heart federation; International. In Circulation. https://doi.org/10.1161/CIRCULATIONAHA.109.192644

Alidosti, M., Sharifirad, G. R., Golshiri, P., Azadbakht, L., Hasanzadeh, A., \& Hemati, Z. (2012). An investigation on the effect of gastric cancer education based on Health Belief Model on knowledge, attitude and nutritional practice of housewives. Iranian Journal of Nursing and Midwifery Research, 17(4).

Baghianimoghadam, M. H., Hadavandkhani, M., Mohammadi, M., Fallahzade, H., \& Baghianimoghadam, B. (2012). Current education versus peer-education on walking in type 2 diabetic patients based on Health Belief Model: a randomised control trial study. Romanian Journal of Internal Medicine = Revue Roumaine de Médecine Interne, 50(2).

Baghianimoghadam, M. H., Shogafard, G., Sanati, H. R., Baghianimoghadam, B., Mazloomy, S. S., \& Askarshahi, M. (2013). Application of the health belief model in promotion of selfcare in heart failure patients. Acta Medica Iranica, 51(1).

Bayat, F., Shojaeezadeh, D. S. M., Heshmat, R., Baikpour, M., \& Hosseini, M. (2013). The effects of education based on extended health belief model in type 2 diabetic patients: A randomised controlled trial. Journal of Diabetes and Metabolic Disorders, 12(1). https://doi.org/10.1186/2251-6581-12-45

Bellastella, G., Bizzarro, A., Aitella, E., Barrasso, M., Cozzolino, D., di Martino, S., Esposito, K., $\&$ de Bellis, A. (2015). Pregnancy may favour the development of severe autoimmune central diabetes insipidus in women with vasopressin cell antibodies: Description of two cases. European Journal of Endocrinology, 172(3). https://doi.org/10.1530/EJE-14-0762

Choo, J., Yoon, S. J., Ryu, H., Park, M. S., Lee, H. S., Park, Y. M., \& Lim, D. S. (2016). The Seoul metropolitan lifestyle intervention program and metabolic syndrome risk: A retrospective database study. International Journal of Environmental Research and Public Health, 13(7). https://doi.org/10.3390/ijerph13070667

De la Iglesia, R., Loria-Kohen, V., Zulet, M. A., Martinez, J. A., Reglero, G., \& de Molina, A. R. (2016). Dietary strategies implicated in the prevention and treatment of metabolic syndrome. In International Journal of Molecular Sciences, 17(11). https://doi.org/10.3390/ijms17111877

Emiral, G. O., Tozun, M., Atalay, B. I., Goktas, S., Dagtekin, G., Aygar, H., Arslantas, D., Unsal, A., Babaoglu, A. B., \& Tirpan, K. (2021). Assessment of knowledge of metabolic 
syndrome and health literacy level among adults in Western Turkey. Nigerian Journal of Clinical Practice, 24(1). https://doi.org/10.4103/njcp.njcp_88_18

Equator. (2020). The EQUATOR Network | Enhancing the QUAlity and Transparency Of Health Research. In Equator Resource Centre.

Farhadi, Z., Roshanaei, G., Bashirian, S., \& Rezapur-Shahkolai, F. (2014). The Effect of an Educational Program on School Injury Prevention in Junior High School Students of Famenin Based on the Health Belief Model. Journal of Education and Community Health, 1(3). https://doi.org/10.20286/jech-010371

Fathi, A., Sharifirad, G., Gharlipour, Z., Hakimelahi, J., \& Mohebi, S. (2017). Effects of a nutrition education intervention designed based on the health belief model (HBM) on reducing the consumption of unhealthy snacks in the sixth grade primary school girls. International Journal of Pediatrics, 5(2). https://doi.org/10.22038/ijp.2016.7567

Fechner, E., Smeets, E. T. H. C., Schrauwen, P., \& Mensink, R. P. (2020). The effects of different degrees of carbohydrate restriction and carbohydrate replacement on cardiometabolic risk markers in humans-a systematic review and meta-analysis. In Nutrients, 12(4). https://doi.org/10.3390/nu12040991

Ghavami, M., Harandy, F. T., \& Kabir, K. (2016). The Effect of Educational Intervention in Promoting Safe Behaviours in a Sample of Iranian Primary School Students: An Application of the Health Belief Model. Global Journal of Health Science, 8(11). https://doi.org/10.5539/gjhs.v8n11p242

Giugliano, D., Ceriello, A., \& Esposito, K. (2008). Are there specific treatments for the metabolic syndrome? In American Journal of Clinical Nutrition, 87(1). https://doi.org/10.1093/ajcn/87.1.8

Glanz, K., Rimer, B. K., \& Viswanath, K. (2008). Theory, research and practice in health behaviour and health education. In Health Education.

Goldenberg, J. Z., Day, A., Brinkworth, G. D., Sato, J., Yamada, S., Jönsson, T., Beardsley, J., Johnson, J. A., Thabane, L., \& Johnston, B. C. (2021). Efficacy and safety of low and very low carbohydrate diets for type 2 diabetes remission: systematic review and metaanalysis of published and unpublished randomised trial data. BMJ (Clinical Research Ed.), 372. https://doi.org/10.1136/bmj.m4743

Hallberg, S. J., Gershuni, V. M., \& Athinarayanan, S. J. (2019). Reversing type 2 diabetes: A narrative review of the evidence. Nutrients, 11(4). https://doi.org/10.3390/nu11040766

Hammer, S., Snel, M., Lamb, H. J., Jazet, I. M., van der Meer, R. W., Pijl, H., Meinders, E. A., Romijn, J. A., de Roos, A., \& Smit, J. W. A. (2008). Prolonged Caloric Restriction in Obese Patients With Type 2 Diabetes Mellitus Decreases Myocardial Triglyceride Content and Improves Myocardial Function. Journal of the American College of Cardiology, 52(12). https://doi.org/10.1016/j.jacc.2008.04.068

Jalilian, F., Motlagh, F. Z., Solhi, M., \& Gharibnavaz, H. (2014). Effectiveness of selfmanagement promotion educational program among diabetic patients based on health belief model. Journal of Education and Health Promotion, 3(1). https://doi.org/10.4103/2277-9531.127580

Janz, N. K., \& Becker, M. H. (1984). The Health Belief Model: A Decade Later. Health Education \& Behaviour, 11(1), 1-47. https://doi.org/10.1177/109019818401100101

Jeihooni, A. K., Hidarnia, A., Kaveh, M. H., \& Hajizadeh, E. (2015). The effect of a prevention program based on health belief model on osteoporosis. Journal of Research in Health Sciences, 15. https://doi.org/10.34172/jrhs151803 
Mahmoud, M. H., Sayed, S. H., Ibrahim, H. A.-F., \& Abd-Elhakam, E. M. (2018). Effect of Health Belief Model-Based Educational Intervention About Breast Cancer on Nursing Students' Knowledge, Health Beliefs and Breast Self-Examination Practice. International Journal of Studies in Nursing, 3(3). https://doi.org/10.20849/ijsn.v3i3.503

Mohamed, H., Al-Lenjawi, B., Amuna, P., Zotor, F., \& Elmahdi, H. (2013). Culturally sensitive patient-centred educational programme for self-management of type 2 diabetes: A randomised controlled trial. Primary Care Diabetes, 7(3).

https://doi.org/10.1016/j.pcd.2013.05.002

Mohammadi, S., Karim, N. A., Talib, R. A., \& Amani, R. (2018). The impact of self-efficacy education based on the health belief model in Iranian patients with type 2 diabetes: A randomised controlled intervention study. Asia Pacific Journal of Clinical Nutrition, 27(3). https://doi.org/10.6133/apjcn.072017.07

National Heart Lung and Blood Institute. (2014). Quality Assessment Tool for Observational Cohort and Cross-Sectional Studies. Bethesda, MD: National Institutes of Health, Department of Health and Human Services.

Neter, J. E., Stam, B. E., Kok, F. J., Grobbee, D. E., \& Geleijnse, J. M. (2003). Influence of Weight Reduction on Blood Pressure: A Meta-Analysis of Randomised Controlled Trials. Hypertension, 42(5). https://doi.org/10.1161/01.HYP.0000094221.86888.AE

Olatona, F. A., Onabanjo, O. O., Ugbaja, R. N., Nnoaham, K. E., \& Adelekan, D. A. (2018). Dietary habits and metabolic risk factors for non-communicable diseases in a university undergraduate population. Journal of Health, Population and Nutrition, 37(1). https://doi.org/10.1186/s41043-018-0152-2

Paisey, R. B., Harvey, P., Rice, S., Belka, I., Bower, L., Dunn, M., Taylor, P., Paisey, R. M., Frost, J., \& Ash, I. (1998). An intensive weight loss programme in established type 2 diabetes and controls: Effects on weight and atherosclerosis risk factors at 1 year. Diabetic Medicine, 15(1). https://doi.org/10.1002/(SICI)1096-9136(199801)15:1<73::AID-DIA516>3.0.CO;2-F

Petersen, J. M., Prichard, I., Kemps, E., \& Tiggemann, M. (2019). The effect of snack consumption on physical activity: A test of the Compensatory Health Beliefs Model. Appetite, 141. https://doi.org/10.1016/j.appet.2019.104342

Petrogianni, M., Kanellakis, S., Kallianioti, K., Argyropoulou, D., Pitsavos, C., \& Manios, Y. (2013). A multicomponent lifestyle intervention produces favourable changes in diet quality and cardiometabolic risk indices in hypercholesterolaemic adults. Journal of Human Nutrition and Dietetics, 26(6). https://doi.org/10.1111/jhn.12041

Phillips, K. M., Carlsen, M. H., \& Blomhoff, R. (2009). Total Antioxidant Content of Alternatives to Refined Sugar. Journal of the American Dietetic Association, 109(1), 64-71. https://doi.org/10.1016/j.jada.2008.10.014

Saboya, P. P., Bodanese, L. C., Zimmermann, P. R., Gustavo, A. Da S., Assumpção, C. M., \& Londero, F. (2016). Metabolic syndrome and quality of life: a systematic review. Revista Latino-Americana de Enfermagem, 24(0). https://doi.org/10.1590/1518-8345.1573.2848

Shahnazi, H., Sabooteh, S., Sharifirad, G., Mirkarimi, K., \& Hassanzadeh, A. (2015). The impact of education intervention on the Health Belief Model constructs regarding anxiety of nulliparous pregnant women. Journal of Education and Health Promotion, 4(1). https://doi.org/10.4103/2277-9531.154120 
Shamsi, M., Sharifirad, G., Kachoyee, A., \& Hassanzadeh, A. (2010). The effect of educational program walking based on health belief model on control suger in woman by type 2 diabetics. Iranian Journal of Endocrinology and Metabolism, 11(5).

Siddiqui, F., Kurbasic, A., Lindblad, U., Nilsson, P. M., \& Bennet, L. (2017). Effects of a culturally adapted lifestyle intervention on cardio-metabolic outcomes: a randomised controlled trial in Iraqi immigrants to Sweden at high risk for Type 2 diabetes. Metabolism: Clinical and Experimental, 66. https://doi.org/10.1016/j.metabol.2016.10.001

Singh, A., Lal, U. R., Mukhtar, H. M., Singh, P. S., Shah, G., \& Dhawan, R. K. (2015). Phytochemical profile of sugarcane and its potential health aspects. In Pharmacognosy Reviews, 9(17). https://doi.org/10.4103/0973-7847.156340

Snel, M., Jonker, J. T., Hammer, S., Kerpershoek, G., Lamb, H. J., Edo Meinders, A., Pijl, H., de Roos, A., Romijn, J. A., Smit, J. W. A., \& Jazet, I. M. (2012). Long-term beneficial effect of a 16-week very low calorie diet on pericardial fat in obese type 2 diabetes mellitus patients. Obesity, 20(8). https://doi.org/10.1038/oby.2011.390

Staessen, J., Fagard, R., \& Amery, A. (1988). The relationship between body weight and blood pressure. In Journal of Human Hypertension, 2(4).

te Morenga, L. A., Howatson, A. J., Jones, R. M., \& Mann, J. (2014). Dietary sugars and cardiometabolic risk: Systematic review and meta-analyses of randomised controlled trials of the effects on blood pressure and lipids. In American Journal of Clinical Nutrition, 100(1). https://doi.org/10.3945/ajcn.113.081521

te Morenga, L. A., Mallard, S., \& Mann, J. (2013). Dietary sugars and body weight: Systematic review and meta-analyses of randomised controlled trials and cohort studies. BMJ (Online). https://doi.org/10.1136/bmj.e7492

Timóteo, A. T. (2018). Diet in patients with metabolic syndrome: What is the ideal macronutrient composition? In Revista Portuguesa de Cardiologia, 37(12). https://doi.org/10.1016/j.repc.2017.11.013

Tougas, M. E., Hayden, J. A., McGrath, P. J., Huguet, A., \& Rozario, S. (2015). A systematic review exploring the social cognitive theory of self-regulation as a framework for chronic health condition interventions. In PLOS ONE. https://doi.org/10.1371/journal.pone.0134977

Van der Heijden, M. M. P., Pouwer, F., Romeijnders, A. C., \& Pop, V. J. M. (2012). Testing the effectiveness of a self-efficacy based exercise intervention for inactive people with type 2 diabetes mellitus: Design of a controlled clinical trial. BMC Public Health, 12(1). https://doi.org/10.1186/1471-2458-12-331

Wing, R. R., Blair, E., Marcus, M., Epstein, L. H., \& Harvey, J. (1994). Year-long weight loss treatment for obese patients with type II diabetes: Does including an intermittent verylow-calorie diet improve outcome?. The American Journal of Medicine, 97(4). https://doi.org/10.1016/0002-9343(94)90302-6

World Health Organization. (2015). WHO Guideline: Sugars intake for adults and children. In WHO Library Cataloguing-in-Publication Data.

Yokokawa, H., Fukuda, H., Yuasa, M., Sanada, H., Hisaoka, T., \& Naito, T. (2016). Association between health literacy and metabolic syndrome or healthy lifestyle characteristics among community-dwelling Japanese people. Diabetology and Metabolic Syndrome, 8(1). https://doi.org/10.1186/s13098-016-0142-8

Zareban, I., Karimy, M., Niknami, S., Haidarnia, A., \& Rakhshani, F. (2014). The effect of selfcare education program on reducing $\mathrm{HbA1c}$ levels in patients with type 2 diabetes. Journal of Education and Health Promotion, 3(123). 
INTERNATIONAL JOURNAL OF ACADEMIC RESEARCH IN BUSINESS AND SOCIAL SCIENCES

Vol. 11, No. 19, Youth and Community Wellness, 2021, E-ISSN: 2222-6990 @ 2021 HRMARS

File 1: Quality appraisal of the included studies.

\begin{tabular}{|c|c|c|c|c|c|c|c|c|c|c|c|c|c|c|c|}
\hline $\begin{array}{l}\text { Studies } \\
\text { (Author } \\
\text {, year, } \\
\text { country } \\
\text { ) }\end{array}$ & $\begin{array}{l}\text { Was } \\
\text { the } \\
\text { study } \\
\text { describ } \\
\text { ed as } \\
\text { rando } \\
\text { mised, } \\
\text { a } \\
\text { rando } \\
\text { mised } \\
\text { trial, a } \\
\text { rando } \\
\text { mised } \\
\text { clinical } \\
\text { trial, or } \\
\text { an } \\
\text { RCT? }\end{array}$ & $\begin{array}{l}\text { Was the } \\
\text { method } \\
\text { of } \\
\text { randomi } \\
\text { sation } \\
\text { adequat } \\
\text { e (i.e., } \\
\text { use of } \\
\text { randoml } \\
\text { y } \\
\text { generat } \\
\text { ed } \\
\text { assignm } \\
\text { ent)? }\end{array}$ & $\begin{array}{l}\text { Was the } \\
\text { treatme } \\
\text { nt } \\
\text { allocatio } \\
\mathrm{n} \\
\text { conceal } \\
\text { ed (so } \\
\text { that } \\
\text { assignm } \\
\text { ents } \\
\text { could } \\
\text { not be } \\
\text { predicte } \\
\text { d)? }\end{array}$ & $\begin{array}{l}\text { Were } \\
\text { study } \\
\text { particip } \\
\text { ants and } \\
\text { provider } \\
\text { s } \\
\text { blinded } \\
\text { to } \\
\text { treatme } \\
\text { nt group } \\
\text { assignm } \\
\text { ent? }\end{array}$ & $\begin{array}{l}\text { Were } \\
\text { the } \\
\text { people } \\
\text { assessi } \\
\text { ng the } \\
\text { outco } \\
\text { mes } \\
\text { blinde } \\
\text { d to } \\
\text { the } \\
\text { partici } \\
\text { pants' } \\
\text { group } \\
\text { assign } \\
\text { ments } \\
\text { ? }\end{array}$ & $\begin{array}{l}\text { Were the } \\
\text { groups } \\
\text { similar at } \\
\text { baseline } \\
\text { on } \\
\text { important } \\
\text { characteri } \\
\text { stics that } \\
\text { could } \\
\text { affect } \\
\text { outcomes } \\
\text { (e.g., } \\
\text { demograp } \\
\text { hics, risk } \\
\text { factors, } \\
\text { co-morbid } \\
\text { condition } \\
\text { s)? }\end{array}$ & $\begin{array}{l}\text { Was } \\
\text { the } \\
\text { overall } \\
\text { drop- } \\
\text { out } \\
\text { rate } \\
\text { from } \\
\text { the } \\
\text { study } \\
\text { at } \\
\text { endpoi } \\
\text { nt } 20 \% \\
\text { or } \\
\text { lower } \\
\text { of the } \\
\text { numbe } \\
\text { r } \\
\text { allocat } \\
\text { ed to } \\
\text { treatm } \\
\text { ent? }\end{array}$ & $\begin{array}{l}\text { Was } \\
\text { the } \\
\text { differe } \\
\text { ntial } \\
\text { drop- } \\
\text { out } \\
\text { rate } \\
\text { (betwe } \\
\text { en } \\
\text { treatm } \\
\text { ent } \\
\text { groups } \\
\text { ) at } \\
\text { endpoi } \\
\text { nt } 15 \\
\text { percen } \\
\text { tage } \\
\text { points } \\
\text { or } \\
\text { lower? }\end{array}$ & $\begin{array}{l}\text { Was } \\
\text { there } \\
\text { high } \\
\text { adhere } \\
\text { nce to } \\
\text { the } \\
\text { interve } \\
\text { ntion } \\
\text { protoc } \\
\text { ols for } \\
\text { each } \\
\text { treatm } \\
\text { ent } \\
\text { group? }\end{array}$ & $\begin{array}{l}\text { Were } \\
\text { other } \\
\text { interventi } \\
\text { ons } \\
\text { avoided } \\
\text { or similar } \\
\text { in the } \\
\text { groups } \\
\text { (e.g., } \\
\text { similar } \\
\text { backgrou } \\
\text { nd } \\
\text { treatment } \\
\text { s)? }\end{array}$ & $\begin{array}{l}\text { Were } \\
\text { outcom } \\
\text { es } \\
\text { assessed } \\
\text { using } \\
\text { valid } \\
\text { and } \\
\text { reliable } \\
\text { measure } \\
\text { s, } \\
\text { implem } \\
\text { ented } \\
\text { consiste } \\
\text { ntly } \\
\text { across } \\
\text { all study } \\
\text { particip } \\
\text { ants? }\end{array}$ & $\begin{array}{l}\text { Did } \\
\text { the } \\
\text { author } \\
\text { s } \\
\text { report } \\
\text { that } \\
\text { the } \\
\text { sample } \\
\text { size } \\
\text { was } \\
\text { sufficie } \\
\text { ntly } \\
\text { large } \\
\text { to be } \\
\text { able to } \\
\text { detect } \\
\text { a } \\
\text { differe } \\
\text { nce in } \\
\text { the } \\
\text { main } \\
\text { outco } \\
\text { me } \\
\text { betwe } \\
\text { en } \\
\text { groups } \\
\text { with at } \\
\text { least } \\
80 \%\end{array}$ & $\begin{array}{l}\text { Wer } \\
\text { e } \\
\text { outc } \\
\text { ome } \\
\text { s } \\
\text { rep } \\
\text { orte } \\
\text { d or } \\
\text { sub } \\
\text { gro } \\
\text { ups } \\
\text { anal } \\
\text { yse } \\
\text { d } \\
\text { pres } \\
\text { peci } \\
\text { fied } \\
\text { (i.e., } \\
\text { iden } \\
\text { tifie } \\
\text { d } \\
\text { bef } \\
\text { ore } \\
\text { anal } \\
\text { yses } \\
\text { wer } \\
\text { e } \\
\text { con }\end{array}$ & $\begin{array}{l}\text { Were } \\
\text { all } \\
\text { rando } \\
\text { mised } \\
\text { partici } \\
\text { pants } \\
\text { analys } \\
\text { ed in } \\
\text { the } \\
\text { group } \\
\text { to } \\
\text { which } \\
\text { they } \\
\text { were } \\
\text { original } \\
\text { ly } \\
\text { assigne } \\
\text { d, i.e., } \\
\text { did } \\
\text { they } \\
\text { use an } \\
\text { intenti } \\
\text { on-to- } \\
\text { treat } \\
\text { analysi } \\
\text { s? }\end{array}$ & $\begin{array}{l}\text { Tota } \\
\text { I } \\
\text { (Yes } \\
\text { ) } \\
\text { *Yes } \\
=1, \\
\text { No= } \\
0\end{array}$ \\
\hline
\end{tabular}


INTERNATIONAL JOURNAL OF ACADEMIC RESEARCH IN BUSINESS AND SOCIAL SCIENCES

Vol. 11, No. 19, Youth and Community Wellness, 2021, E-ISSN: 2222-6990 @ 2021 HRMARS

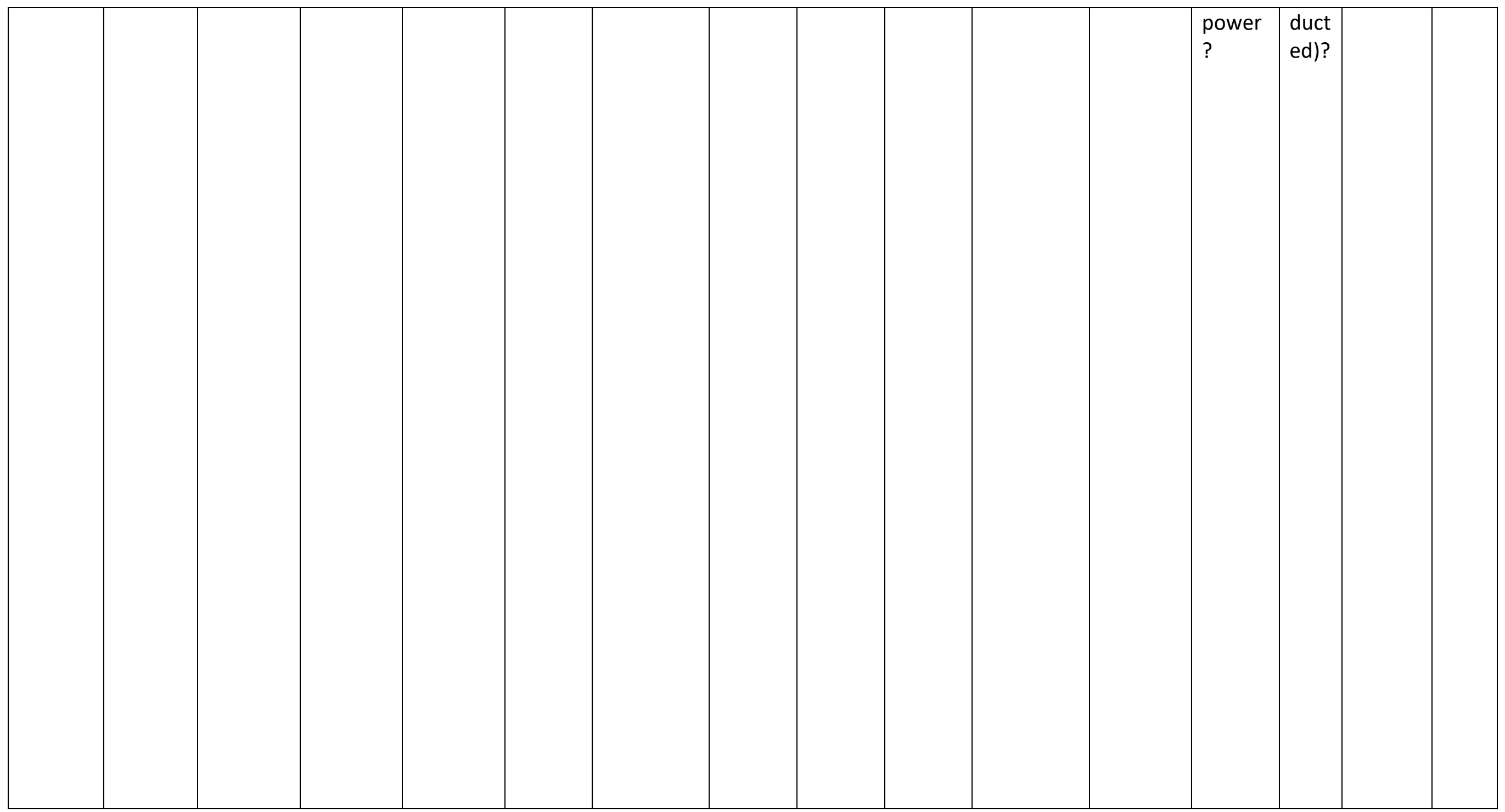


INTERNATIONAL JOURNAL OF ACADEMIC RESEARCH IN BUSINESS AND SOCIAL SCIENCES

Vol. 11, No. 19, Youth and Community Wellness, 2021, E-ISSN: 2222-6990 @ 2021 HRMARS

\begin{tabular}{|c|c|c|c|c|c|c|c|c|c|c|c|c|c|c|c|}
\hline $\begin{array}{l}\text { Bayat } \\
\text { et al., } \\
2013, \\
\text { Iran }\end{array}$ & 1 & 1 & 1 & 0 & 0 & 1 & 1 & 1 & 1 & 1 & 1 & 1 & 1 & 0 & 11 \\
\hline $\begin{array}{l}\text { Moham } \\
\text { ed et } \\
\text { al., } \\
2013, \\
\text { Qatar }\end{array}$ & & & & & & & & & & & & & & & \\
\hline & 1 & 1 & 1 & 0 & 0 & 1 & 0 & 0 & 1 & 1 & 1 & 1 & 1 & 1 & 10 \\
\hline $\begin{array}{l}\text { Petrogi } \\
\text { anni et } \\
\text { al., } \\
2013, \\
\text { Greece }\end{array}$ & & & & & & & & & & & & & & & \\
\hline & 1 & NR & 1 & 0 & 0 & 1 & 1 & 1 & 1 & 1 & 1 & 0 & 1 & 0 & 9 \\
\hline $\begin{array}{l}\text { Jalilian } \\
\text { et al., } \\
2014, \\
\text { Iran }\end{array}$ & 1 & NR & 1 & 0 & 0 & 1 & 1 & 1 & 1 & 1 & 1 & 0 & 1 & 0 & 9 \\
\hline $\begin{array}{l}\text { Zareba } \\
\text { n et al., } \\
2014, \\
\text { Iran }\end{array}$ & 1 & NR & 1 & 0 & 1 & 1 & 1 & 1 & 1 & 1 & 1 & 1 & 1 & 1 & 12 \\
\hline
\end{tabular}


INTERNATIONAL JOURNAL OF ACADEMIC RESEARCH IN BUSINESS AND SOCIAL SCIENCES

Vol. 11, No. 19, Youth and Community Wellness, 2021, E-ISSN: 2222-6990 @ 2021 HRMARS

\begin{tabular}{|c|c|c|c|c|c|c|c|c|c|c|c|c|c|c|c|}
\hline $\begin{array}{l}\text { Abdula } \\
\text { h et al., } \\
2018, \\
\text { Iraq }\end{array}$ & 1 & 1 & 1 & 1 & 1 & 1 & 1 & 1 & 1 & 1 & 1 & 1 & 1 & 1 & 14 \\
\hline $\begin{array}{l}\text { Moham } \\
\text { madi et } \\
\text { al., } \\
\text { 2018, } \\
\text { Iran }\end{array}$ & 1 & 1 & 1 & 0 & 0 & 1 & 1 & 1 & 1 & 1 & 1 & 0 & 1 & 0 & 10 \\
\hline
\end{tabular}

*NR=not reported 